\title{
"Babysitting" procedures in proximal nerve trunk injuries: two case reports and a review
}

\author{
Michele R. Colonna ${ }^{1}$, Antonio Russo ${ }^{2}$, Mariarosaria Galeano ${ }^{3}$, Gabriele Delia1, \\ Giorgio E. Pajardi', Francesco Stagno d'Alcontres ${ }^{1}$
}

${ }^{1}$ Department of Experimental Specialistic Medical and Surgical Sciences and Odontostomatology, University of Messina, 98121 Messina, Italy. ${ }^{2}$ Department Hand Surgery, Multimedica Hospital, 20122 Milan, Italy.

${ }^{3}$ Department of Surgical Specialties, University Hospital of Messina, 98125 Messina, Italy.

${ }^{4}$ Department of Clinical and Community Sciences, University of Milan, 20122 Milan, Italy.

Address for correspondence: Prof. Michele R. Colonna, Department of Experimental Specialistic Medical and Surgical Sciences and Odontostomatology, University of Messina, 98121 Messina, Italy. E-mail: mrcolonna1@gmail.com

\begin{abstract}
One of the most important goals in treating proximal nerve injuries is to maintain the function of distal effectors during axonal regeneration. "Babysitting", that is, connecting the injured nerve to a healthy trunk provides a bypass for distal neural regeneration or reactivation. It avoids degeneration of sensory and motor terminations, with minimal donor nerve damage. We present a technique where a nerve graft is used between ulnar and median nerve through two end-to-side sutures in the distal third of the forearm, in two different cases of proximal ulnar nerve injury. Both patients were young manual workers, the former suffered a total nerve disruption proximal to the elbow following a car accident and the latter suffered a perineurial scar from a high voltage injury at the proximal third of the forearm. The proximal injury was grafted with a sural nerve in the former and treated by neurolysis in the latter. Results were graded by the Highet-Zachary scale for both sensory and motor recovery. The outcomes of our series were compared to six other case reports in the literature (including median nerves) treated with this technique. Both clinical and experimental data show that babysitting effectively protects distal effectors.
\end{abstract}

Key words:

Denervation, end-to-side neural repair, Martin Gruber anastomosis, nerve graft, sensory recovery

\section{INTRODUCTION}

Proximal nerve injuries are well-known to produce atrophy of the distal effectors. This is evident in injuries of major nerve trunks in the upper limb. The ulnar nerve has shown to have the lowest regenerative rate. ${ }^{[1,2]}$ Distal neurotization through end-to-side coaptation has been

\begin{tabular}{|l|l|}
\hline \multicolumn{2}{|c|}{ Access this article online } \\
\hline Quick Response Code: & Website: \\
\hline & www.parjournal.net \\
\hline & \\
\hline
\end{tabular}

employed $^{[3]}$ to bring new axons into distal effectors in case of proximal nerve trunk injury to avoid distal effector degeneration. End-to-side nerve repair is a microsurgical technique in which nerve fibers are transferred from an intact donor nerve to a denervated recipient nerve directly or through a bridge graft. ${ }^{[4]}$ Although the value of end-to-side coaptation is debated in the literature, good functional results can be achieved when this technique is applied with special care to the donor nerve. ${ }^{[6]}$

The "babysitter" procedure combines ${ }^{[5]}$ cross-facial nerve grafting with the segmental transfer of the hypoglossal nerve to the affected facial nerve. This technique has shown satisfactory to excellent results. In long-lasting paralysis, nonetheless, the babysitter procedure may need to be combined with muscle(s) flap(s) for enhanced outcomes..$^{[5,8]}$ 
The authors report two cases of ulnar nerve injury proximal to the elbow: a double end-to-side coaptation through a nerve graft allowed axons from the donor median nerve to rehabilitate the recipient ulnar nerve (a surgically induced Martin Gruber anastomosis). This model was recently proposed by Kayikcioglu et al. ${ }^{[9]}$ and Magdi Sherif and Amr. ${ }^{[10]}$ In our cases, proximal ulnar nerve repair was performed through a long traditional nerve graft by end-to-end coaptation in the former, and by neurolysis in the latter. In both cases, a Zancolli lasso procedure was added distally. Our results are compared to six cases that were previously published and the effects of injury type, time from the initial trauma, surgical techniques, and future perspectives are discussed.

\section{CASE REPORT}

\section{Case I}

A 22-year-old man, a hand worker, presented with proximal left ulnar nerve injury. He was found to have head trauma and an open contaminated wound of the left elbow with more than $12 \mathrm{~cm}$ of missing ulnar nerve. The wound was found to be contaminated with Actinobacter baumanii. Extensive debridement of the wound was carried out, and a cable graft from the sural nerve was performed 1 month after. A small remnant of the cutaneous medialis antebrachii nerve was found during scar removal, and it was used for the babysitting procedure.

At the distal third of the volar aspect of the forearm, $5 \mathrm{~cm}$ proximal to the distal palmar wrist crease, almost $4 \mathrm{~cm}$ of both the median and the ulnar nerve were exposed [Figure 1]. On both trunks, an epiperineural window was created on both the sides containing motor fascicles, the palmar ulnar side of the median nerve and the palmar radial side of the ulnar nerve, respectively (no stimulation was used). The 2 windows were connected through the graft obtained from the cutaneous antebrachii, which was sutured to the main trunks with 2 11-0 nylon sutures on each side [Figure 2]. Furthermore, the "lasso" procedure described by Zancolli

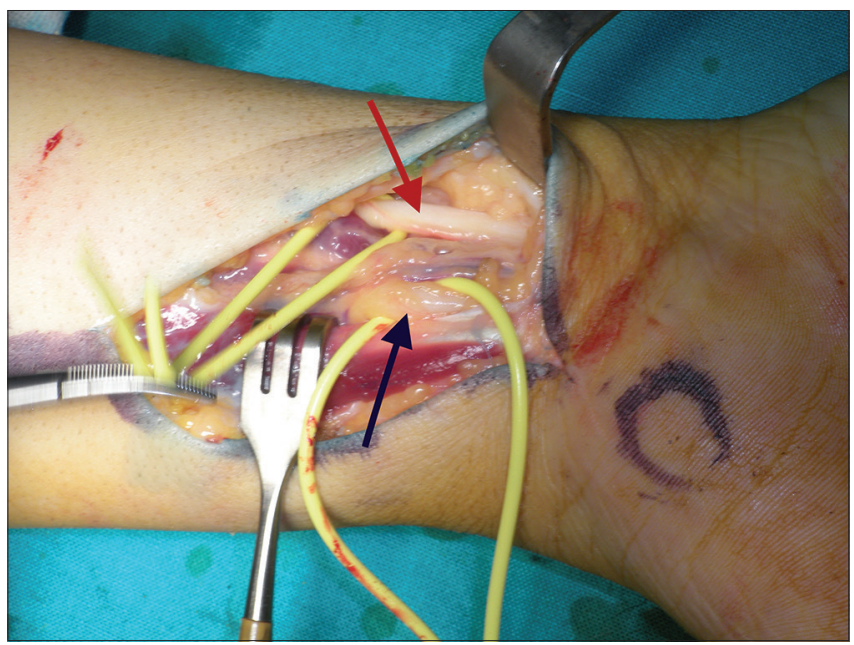

Figure 1: Planning of the procedure: at the distal third of the volar aspect of the forearm, $5 \mathrm{~cm}$ proximal to the distal palmar wrist crease, almost $4 \mathrm{~cm}$ of both the median (red arrow) and the ulnar (black arrow) nerve are exposed (label median and ulnar nerve) was performed on the 4th and 5th digits. The hand was casted for immobilization, and the elbow was maintained in semi-extended position for 20 days, followed by progressive elbow mobilization.

The Highet-Zachary scheme was applied for motor evaluation, and a modification of Mackinnon et al..$^{[1]}$ Sensory recovery scale was used with static and moving 2-point discrimination test. Early (20 days) protective sensation recovery was registered, but the 36-month and 6-year follow-up showed poor outcomes both for sensation ( $\mathrm{S} 1$ ) and motion (M0).

\section{Case 2}

A 46-year-old man presented with proximal ulnar nerve injuries following a high voltage injury to the upper third of his left forearm. Three months after trauma, an electrophysiological study was performed which showed the absent motor and sensory potentials. An extensive surgical exposure and external neurolysis were performed together with distal babysitting technique. The terminal branch of the cutaneous medialis antebrachii was taken during ulnar exposure, and it was used as bridge graft without nerve stimulation; a Zancolli lasso procedure was also performed on the fourth and fifth digits. After two weeks, sensory and motor rehabilitation began following the same protocol applied to the first patient.

Outcome evaluation was performed as in case 1 . Also in this case, early protective sensation recovery (24 days) was registered at 12-month follow-up. This high-voltage injury showed good results (S5 and M4) at 12-month follow-up.

\section{DISCUSSION AND REVIEW}

Denervation after nerve injury is known to cause important structural and functional changes within skeletal muscle, and long-term denervation with improper axonal recruitment has shown to produce atrophy of the end

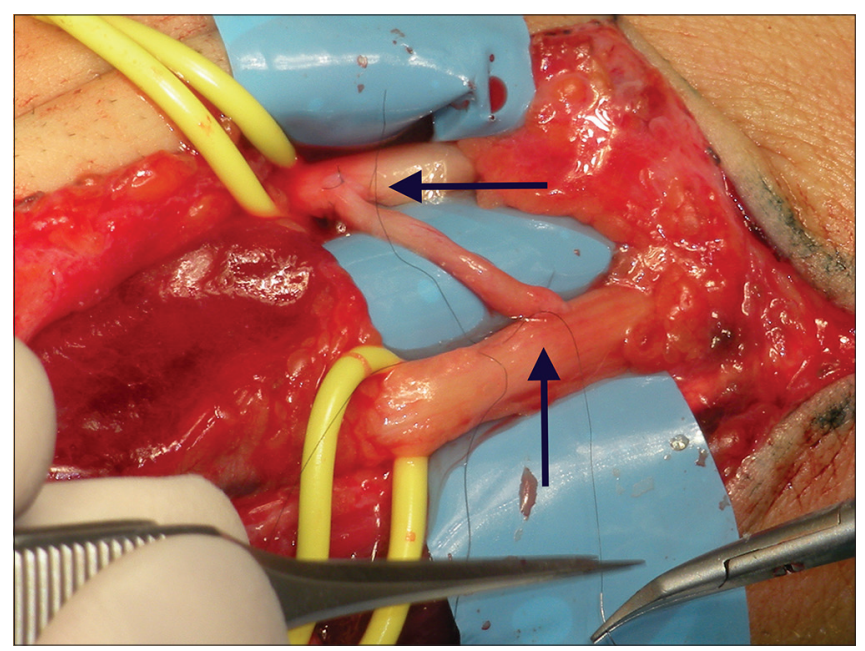

Figure 2: On both trunks, an epiperineural window has been opened, on both the sides containing motor fascicles, the palmar ulnar side of the median nerve and the palmar radial side of the ulnar nerve, respectively. The two windows have been connected through a cross graft of the cutaneous antebrachii, which was sutured (arrows) to the main trunks with two 11-0 nylon sutures on each side (label) 
organs (both motor and sensory). ${ }^{[1,2]}$ Nerve babysitting ${ }^{[3-5]}$ provides distal effector organs (muscle, skin) reinnervation through end-to-side and side-to-side neurotization coming from healthy donor nerves when a proximal nerve trunk repair has been done. The rationale of using this technique are: (a) distal sensory corpuscles (Pacinian and Meissner) as well as motor plates undergo atrophy after denervation; ${ }^{[1]}$ (b) creating a connection distal to the injury, in a safe territory with the least damage to the donor nerve is a desirable goal when repairing a proximal nerve injury. ${ }^{[3-5,8]}$ However, experimental studies reported that mixing sensory and motor axons allows gain of sensation but fails in motor reinnervation. ${ }^{[11]}$ Moreover, Wallerian degeneration with time produces a poorer turnover and attraction of Schwann cells as well as a lower production of specific neurite growth factors; ${ }^{[12-14]}$ and (c) both clinical and experimental evidences have showed that donor axons can be induced into a recipient trunk through an opening of the epiperineurial connective tissue, ${ }^{[3,6]}$ and the capability of axonal attraction through a nerve graft used as a bridge through two different nerve trunks has also been demonstrated. ${ }^{[4]}$ This could also be achieved using epineurial windows bridged with autologous vein as shown in a previous study. ${ }^{[15]}$

Six cases have been published in the literature. First, Kayikcioglu et al..$^{[9]}$ reported 2 cases of neural graft bridging the median and ulnar nerve (creating a Martin Gruber connection distal to the injury) just proximal to the wrist in a case of a median nerve cut at the elbow and of ulnar injury $5 \mathrm{~cm}$ proximal to the medial epicondyle. They reported poor motor sand sensate results. Afterward Magdi Sherif and Amr ${ }^{[10]}$ reported 4 patients with ulnar or median nerve proximal lesions, which were treated with a modified Kayikcioglu's technique for comparison of main features of injuries and repair [Table 1]. In this paper, we report our experience with the application of a modified Kayikcioglu's technique to 2 patients. To date, a total of 8 proximal nerve injuries have been treated by this method (includes two cases from this report): 5 ulnar and 3 median nerves.

Magdi Sherif and Amr ${ }^{[10]}$ reported their best results in median nerve effector protection; dealing with ulnar nerve, they report a good result in a proximal (arm)

Table 1: Comparing main features of nerve injuries in the published series

\begin{tabular}{|c|c|c|c|c|c|c|c|c|c|}
\hline Study & $\begin{array}{l}\text { Patient } \\
\text { number }\end{array}$ & $\begin{array}{l}\text { Genderl } \\
\text { age } \\
\text { (years) }\end{array}$ & Nerve & $\begin{array}{l}\text { Level of } \\
\text { injury }\end{array}$ & Trauma & $\begin{array}{l}\text { Repair and } \\
\text { time from } \\
\text { trauma }\end{array}$ & Protection & $\begin{array}{l}\text { Follow-up } \\
\text { (months) }\end{array}$ & $\begin{array}{l}\text { Outcome } \\
M \text { and S }\end{array}$ \\
\hline & 2 & Male/58 & Ulnar & $\begin{array}{l}\text { Mid right } \\
\text { arm }\end{array}$ & Aggression & $\begin{array}{l}\text { Direct } \\
\text { immediate } \\
\text { exploration and } \\
\text { repair }\end{array}$ & $\begin{array}{l}\text { Cross nerve graft } \\
\text { above the wrist } \\
\text { (four cables from } \\
\text { sural); donor of } \\
\text { axons: median }\end{array}$ & 21 & $\begin{array}{l}\mathrm{S} \text { and } \mathrm{M} \\
\text { poor }\end{array}$ \\
\hline \multirow[t]{4}{*}{$\begin{array}{l}\text { Magdi Sherif } \\
\text { and Amr }{ }^{[10]}\end{array}$} & 1 & Male/34 & Median & $\begin{array}{l}\text { Left forearm } \\
\text { elbow }\end{array}$ & $\begin{array}{l}\text { Tangential } \\
\text { trauma } \\
\text { disruption }\end{array}$ & $\begin{array}{l}\text { Sural graft four } \\
\text { cables; third } \\
\text { intervention } \\
\text { after trauma }\end{array}$ & $\begin{array}{l}\text { Cross nerve graft } \\
\text { in palm between } \\
\text { motor branches } \\
\text { (one cable); donor } \\
\text { of axons: ulnar }\end{array}$ & 12 & $\begin{array}{l}\text { Complete } \\
\text { S and M } \\
\text { recovery }\end{array}$ \\
\hline & 2 & Male/23 & Ulnar & $\begin{array}{l}\text { Mid left } \\
\text { forearm }\end{array}$ & Broken glass & $\begin{array}{l}\text { Sural graft } \\
\text { three cables; } 6 \\
\text { months after }\end{array}$ & $\begin{array}{l}\text { Cross nerve graft } \\
\text { above the wrist } \\
\text { (one cable); donor } \\
\text { of axons: median }\end{array}$ & 9 & M3 S3 \\
\hline & 3 & Female/49 & Ulnar & $\begin{array}{l}\text { Medial } \\
\text { aspect arm }\end{array}$ & Broken glass & $\begin{array}{l}\text { No mention } \\
\text { (direct?); } \\
2 \text { months after }\end{array}$ & $\begin{array}{l}\text { Cross nerve graft } \\
\text { above the wrist } \\
\text { (one cable); donor } \\
\text { of axons: median }\end{array}$ & 9 & $\begin{array}{l}\text { M4; no } \\
\text { mention of S }\end{array}$ \\
\hline & 4 & Female/8 & Median & $\begin{array}{l}\text { Left cubital } \\
\text { fossa }\end{array}$ & Broken glass & $\begin{array}{l}\text { Direct; } \\
\text { immediate } \\
\text { exploration and } \\
\text { repair }\end{array}$ & $\begin{array}{l}\text { Cross nerve graft } \\
\text { above the wrist } \\
\text { (one cable); donor } \\
\text { of axons: ulnar }\end{array}$ & 4 & $\begin{array}{l}\text { M3; no } \\
\text { mention of S }\end{array}$ \\
\hline \multirow[t]{2}{*}{$\begin{array}{l}\text { Colonna et al. } \\
\text { (in this series) }\end{array}$} & 1 & Male/26 & Ulnar & $\begin{array}{l}\text { Left lower } \\
\text { third arm }\end{array}$ & $\begin{array}{l}\text { Tangential } \\
\text { trauma nerve } \\
\text { disruption }\end{array}$ & $\begin{array}{l}\text { Sural graft } \\
\text { six cables; } \\
\text { 1-month after } \\
\text { trauma }\end{array}$ & $\begin{array}{l}\text { Cross nerve graft } \\
\text { above the wrist } \\
\text { (one cable from } \\
\text { medial cutaneous } \\
\text { antebrachii); donor } \\
\text { of axons: median }\end{array}$ & 18 & $\begin{array}{l}\text { M and S } \\
\text { poor }\end{array}$ \\
\hline & 2 & Male/47 & Ulnar & $\begin{array}{l}\text { Left middle } \\
\text { forearm }\end{array}$ & $\begin{array}{l}\text { High-voltage } \\
\text { injury }\end{array}$ & $\begin{array}{l}\text { Neurolysis; } \\
3 \text { months after }\end{array}$ & $\begin{array}{l}\text { Cross nerve graft } \\
\text { above the wrist } \\
\text { (one cable from } \\
\text { cutaneous medialis } \\
\text { antebrachii); donor } \\
\text { of axons: median }\end{array}$ & 18 & $\begin{array}{l}\text { Complete } \\
\text { recovery }\end{array}$ \\
\hline
\end{tabular}


injury as well as an incomplete outcome (partial sensate recovery, up to hypothenar region, and M3 only for finger abduction-adduction) in a lower (forearm) ulnar nerve injury.

The patients were 6 adult men ( 4 ulnar nerve and 2 median nerve injuries), one woman (ulnar) and an 8-year-old girl (median). With the exception of the child (patient number 4), they all underwent surgical repair 1 month after initial trauma. Optimal results were achieved in median nerves and in the pediatric patient. Interestingly, among the five ulnar nerves treated: (1) two showed good results (the former, unexpected, from the Magdi Sherif and Amr. ${ }^{[10]}$ series, a more proximal injury at arm level, and the latter our case of high voltage injury, but it was more distal and required only a neurolysis); (2) another produced a mediocre recovery (even if the injury was located more distally at forearm level); and (3) the remaining 2 achieving poor results.

Time may also be affecting against both proximal repair and distal babysitting; experimental evidences claim the role of decreasing the recruitment of Schwann cells together with lower production of growth factors when Wallerian degeneration is in process. ${ }^{[12-14]}$ Patient number three has the best outcome for the most proximal injury as an earlier combined treatment possibly led to better results than the same treatment in a more distal injury repaired later.

From a clinical point of view, it can be said that proximal ulnar injuries maintain their black legend of poor recovery prognosis while median nerve injuries have a better chance. This occurs especially in case of old (more than two months) injuries.

Cross nerve grafts above the wrist have proven ineffective in bringing axons distally to protect effectors in both Kayikcioglu's et al. ${ }^{[9]}$ and one case from our series. In Magdi Sherif and Amr. ${ }^{[10]}$ series, three cases treated by nerve bridging above the wrist showed good results in one median nerve (a child, see below for further considerations) and an ulnar nerve (M4), as well as mediocre results in another ulnar nerve. This could be explained by worse prognosis dealing with a ulnar nerve; time from injury could also have had a negative influence, whereas the good result (M4) in the other case remains surprising.

These considerations could also apply to our series: two ulnar nerves, the former showing poor outcome, the latter a complete recovery. Some other recommendations must be taken into consideration, too, such as selecting pure motor donor fibers through electrostimulation following Jabaley's et al. ${ }^{[16]}$ topographical anatomy.

However, another consideration is that there is no consensus about the negative influence of sensate fibers. Some authors' ${ }^{\prime 17,18]}$ experience agrees with this last opinion, but several other and more recent experimental experiences $^{[19-22]}$ do not. In these studies, sensate fibers produce end-to-side regeneration and reinnervation of distal muscle. ${ }^{[23,24]}$ Thus, we believe that sensate fibers' negative role should be reconsidered. In pediatric patients, special regenerative and brain adaptive properties should be considered. The pediatric patient in Magdi Sherif and Amr ${ }^{[10]}$ stimulates further comments. Even ulnar nerve lesions that have the worst outcome in adults, seem to produce better outcomes in children. In their series, Magdi Sherif and Amr. ${ }^{[10]}$ showed electrical conduction in both grafts due to child's regenerative capability. They also reported "minimal intrinsic muscle wasting" as an effect of possible damage to the donor nerve produced by end-to-side surgical coaptation (the so-called "escape effect"). Interestingly, this is the only clinical report of this fearful complication of axonal escape from the donor ulnar in that series. Finally, the last technical concern could be risen regarding the number of bridge grafts ("cables") needed to produce the best result; even, in this case, Magdi Sherif and Amr. ${ }^{[10]}$ make the correct comment: the treated cases suggest that higher quantity should not be a valid concern to attract more axons and one cable is enough.

Cross nerve grafts in the palm, such as in patient number one by Magdi Sherif and Amr., ${ }^{10]}$ as connecting pure motor branches, produce better results. We agree that this could due to a pure motor axonal component as well as due to decreased distance for regenerating fibers from the donor nerve. We add that the higher number of axons in the motor branch of the ulnar nerve could also be claimed as a cause. However, the authors $^{[10]}$ noted a difficult dissection of the deep ulnar motor branch, owing to the presence of closer important anatomical structures. Moreover, there is a lack of description of the surgical technique: the authors do not explain where the cable between the median thenar and ulnar motor branch is positioned whether subcutaneous or deep.

We believe that Magdi Sherif and Amr. ${ }^{[10]}$ have refined the original technique, and their recommendations should be followed when applying this technique of babysitting. We recommend one cable grafting, use of stimulator, and most distal grafting to avoid fiber escape and muscle wasting in the territory of the donor nerve. Another negative factor to be struggled is time, which produces a decrease in neurite growth factors and Schwann cells migration. This could be achieved through a microsurgical approach coupled with basic sciences applications, such as gene therapy and tissue engineering with scaffolds and regenerating cells. ${ }^{[25]}$ Moreover, early exploration of nerve injuries could also help in struggle against time and Wallerian degeneration, ${ }^{[26]}$ its rationale is based on both experimental evidences of early neuronal death as far as in motor ventral horn and in dorsal root ganglia ${ }^{27]}$ and more recent clinical data from early brachial plexus exploration and repair. ${ }^{[28]}$ Regardless of final outcomes, coupling of (a) both neurons (neuroprotection) ${ }^{[27]}$ and effectors (babysitting in wrist or palm) ${ }^{[9,10]}$ is preferred to (b) traditional repair through grafts $^{[2]}$ or distal neurotization $^{[29-31]}$ could be regarded as the future in management of proximal nerve injuries. 


\section{REFERENCES}

I. MacKinnon SE, Dellon AD. Anatomy and physiology of the peripheral nerve. Sensory receptors. Surgery of the Peripheral Nerve. New York: Thieme; |988. p. 26-31.

2. Millesi H. Nerve graft indication techniques and prognosis. In: Omer GE, Spinner M, van Beek AL editors. Management of Peripheral Nerve Problems. Philadelphia: WB Saunders; 1998. p. 280-90.

3. Viterbo F, Trindade JC, Hoshino K, Mazzoni Neto A. End-to side neurorraphy with removal of the epineural sheath. Plast Reconstr Surg 1994;94: 1038-47.

4. Viterbo F, Trindade JC, Hoshino K, Mazzoni A. Two end-to-side neurorraphies and nerve grafts with removal of epineurial sheath: experimental study in rats. Br J Plast Surg 1994;47:75-80.

5. Terzis JK, Tzafetta K. "Babysitter" procedure with concomitant muscle transfer in facial paralysis. Plast Reconstr Surg 2009; 124: | | 42-56.

6. Lundborg G, Zhao Q, Kanje M, Danielsen N, Kerns JM. Can Sensory and motor collateral sprouting be induced from intact peripheral nerve by end-to-side anastomosis? J Hand Surg Br 1994; 19:227-82.

7. Kostakoğlu N. Motor and sensory reinnervation in the hand after an end-to-side median to ulnarnerve coaptation in the forearm. Br J Plast Surg 1999;52:404-7.

8. Cederna PS, Kallainen LK, Urbanchek MG, Rovak JM, Kuxzon WM Jr. "Donor" muscle structure and function after end-to-side neurorrhaphy. Plast Reconstr Surg 200 I;107:789-96.

9. Kayikcioglu A, Karamursel S, Agaoglu G, Kecick A, Celiker R, Cetin A End-to-side neurorrhaphy of the ulnar and median nerves at the wrist: report of two cases without sensory or motor improvement. Ann Plast Surg 2000;45:64I-3

10. Magdi Sherif $\mathrm{M}, \mathrm{Amr} \mathrm{AH}$. Intrinsic hand muscle reinnervation by median-ulnar end-to-side bridge nerve graft: case report. J Hand Surg Am 20 I0;35:446-50.

II. Sulaiman OA, Midha R, Munro CA, Matsuyama T, Al-Mayed A, Gordon T. Chronic Schwann cell denervation and the presence of sensory nerve reduce motor axonal regeneration. Exp Neurol 2002; 176:342-54.

12. Sulaiman OA, Gordon T. Effects of short-and long-term Schwann cel denervation on peripheral nerve regeneration, myelination, and size. Glic 2000;32:232-46.

13. Borisov AB, Dedkov El, Carlson BM. Interrelations of myogenic response, progressive atrophy of muscle fibers, and cell death in denervated skeletal muscle. Anat Rec 2001;264:203-18.

14. Kawabuchi M, Zhou CJ, Wang S, Nakamura K, Liu WT, Hirata K. The spatiotemporal relationship among Schwann cells, axons and postsynaptic acetylcholine receptor regions during muscle reinnervation in aged rats. Anat Rec 2001;264:183-202

15. Manasseri B, Raimondo S, Geuna S, Risitano G, D'Alcontres FS. Ulnar nerve repair by end-to-side neurorrhaphy on the median nerve with interposition of a vein: an experimental study. Microsurgery 2007;27:27-3I.

16. Jabaley ME, Wallace WH, Heckler FR. Internal topography of major nerves of the forearm and hand: a current view. J Hand Surg Am 1980;5: I- 18.

17. Nichols CM, Brenner MJ, Fox IK, Tung TH, Hunter DA, Rickman SR, Mackinnon SE. Effects of motor versus sensory nerve grafts on peripheral nerve regeneration. Exp Neurol 2004;190:347-55.
18. Ray WZ, Mackinnon SE. Management of nerve gaps: autografts, allografts, nerve transfers, and end-to-side neurorrhaphy. Exp Neurol 2010;223:77-85.

19. Zuijdendorp HM, Tra WM, van Neck JW, Mollis L, Coert JH. Delay of denervation atrophy by sensory protection in an end-to-side neurorrhaphy model: a pilot study. J Plast Reconstr Aesthet Surg 2010;63:1949-5.

20. Ladak A, Schembri P, Olson J, Udina E, Tyreman N, Gordon T. Double end-to-side nerve grafts sustain chronically denervated peripheral nerve pathways during axon regeneration and result in improved functional reinnervation. Neurosurgery 20 I /;68:1654-65.

21. Li QT, Zhang PX, Yin XF, Han N, Kou YH, Deng JX, Jiang BG. Functional recovery of denervated skeletal muscle with sensory or mixed nerve protection: a pilot study. PLoS One 2013;7:e79746.

22. Li QT, Zhang P, Yin X, Han N, Kou Y, Jiang B. Early sensory protection in reverse end-to-side neurorrhaphy to improve the functional recovery of chronically denervated muscle in rat: a pilot study. J Neurosurg 2014;121:415-22.

23. Fujiwara T, Matsuda K, Kubo T, Tomita K, Hattori R, Masuoka T, Yano K, Hosokawa K. Axonal supercharging technique using reverse end-to-side neurorrhaphy in peripheral nerve repair: an experimental study in the rat model. J Neurosurg 2007;107:821-9.

24. Beck-Broichsitter BE, Becker ST, Lamia A, Fregnan F, Geuna S, Sinis N. Sensoric protection after median nerve injury: babysitter-procedure prevents muscular atrophy and improves neuronal recovery. Biomed Res Int 20|4;20|4:724|97.

25. Manasseri B, Cuccia G, Moimas S, D'Alcontres FS, Polito F, Bitto A, Altavilla D, Squadrito F, Geuna S, Pattarini L, Zentilin L, Collesi C, Puligadda U, Giacca M, Colonna MR. Microsurgical arterovenous loops and biological templates: a novel in vivo chamber for tissue engineering. Microsurgery 2007;27:623-9.

26. Kay SJP, Wiberg M, and Thornton DJ. Nerves are living structures whose injury requires urgent repair. J Plast Reconstr Aesthet Surg 2010;63:1939-40.

27. Hart AM, Terenghi G, Wiberg $M$. Neuronal death after peripheral nerve injury and experimental strategies for neuroprotection. Neurol Res 2008;30:999-1011.

28. Jivan S, Kumar N, Wiberg M, Kay S. The influence of pre-surgical delay on functional outcome after reconstruction of brachial plexus injuries. J Plast Reconstr Aesthet Surg 2009;62:472-9.

29. Schmidhammer R, Redl H, Hopf R, van der Nest DG, Millesi H. Synergistic terminal motor end-to-side nerve graft repair: investigation in a non-human primate model. Acta Neurochir Suppl 2007;100:97-I0I.

30. Schmidhammer R, Nógrádi A, Szabó A, Redl H, Hausner T, van der Nest DG, Millesi $\mathrm{H}$. Synergistic motor nerve fiber transfer between different nerves through the use of end-to-side coaptation. Exp Neurol 2009;217:388-94.

3I. Brown JM, Yee A, Mackinnon SE. Distal median to ulnar nerve transfers to restore ulnar motor and sensory function within the hand: technical nuances. Neurosurgery 2009;65:966-77.

How to cite this article: Colonna MR, Russo A, Galeano M, Delia G, Pajardi GE, d'Alcontres FS. "Babysitting" procedures in proximal nerve trunk injuries: two case reports and a review. Plast Aesthet Res 2015;2:208-12.

Source of Support: Nil, Conflict of Interest: None declared.

Received: 02-02-2015; Accepted: 05-06-2015 